\title{
Eva Darias-Beautell, ed., Unruly Penelopes and the Ghosts: Narratives of English Canada
}

Libe García Zarranz

\section{(2) OpenEdition \\ 1 Journals}

Electronic version

URL: https://journals.openedition.org/ces/5798

DOI: $10.4000 /$ ces. 5798

ISSN: 2534-6695

Publisher

SEPC (Société d'études des pays du Commonwealth)

\section{Printed version}

Date of publication: 1 April 2014

Number of pages: 119-121

ISSN: 2270-0633

\section{Electronic reference}

Libe García Zarranz, "Eva Darias-Beautell, ed., Unruly Penelopes and the Ghosts: Narratives of English Canada", Commonwealth Essays and Studies [Online], 36.2 | 2014, Online since 15 April 2021, connection on 19 July 2021. URL: http://journals.openedition.org/ces/5798; DOI: https://doi.org/ $10.4000 /$ ces. 5798

This text was automatically generated on 19 July 2021.

\section{cc) (†)}

Commonwealth Essays and Studies is licensed under a Licence Creative Commons Attribution - Pas d'Utilisation Commerciale - Pas de Modification 4.0 International. 


\title{
Eva Darias-Beautell, ed., Unruly Penelopes and the Ghosts: Narratives of English Canada
}

\author{
Libe García Zarranz
}

\section{REFERENCES}

Eva Darias-Beautell, ed. Unruly Penelopes and the Ghosts: Narratives of English Canada.

Wilfrid Laurier UP, 2012. 252 p. ISBN (hb): 978-1-55458-363-8, C\$85.

1 In the provocative study Terrorist Assemblages: Homonationalism in Queer Times, cultural critic Jasbir K. Puar contends that, as opposed to an intersectional model of identity, "an assemblage is more attuned to interwoven forces that merge and dissipate time, space, and body against linearity, coherency, and permanency" (Durham and London: Duke UP, 2007; 212). The field of CanLit, with its multiple potentialities for transformation, contestation, institutionalization, and renewal, can be conceptualized as an assemblage in a constant state of becoming, particularly in a moment where rampant neoliberal ideologies and structures abound. Tracing a number of these poetic, ethical and political processes, the collection Unruly Penelopes and the Ghosts: Narratives of English Canada (2012) stands as a timely contribution to the field, especially in these paradoxical times characterized by conflicting affective responses towards the future of the humanities, in general, and of a discipline such as CanLit, in particular. This volume of essays, which gathers the results of the research project "Penelope's Embroidery: Literary Tradition, Cultural Identities, and Theoretical Discourses in the Anglo-Canadian Fiction of the late 20th Century," tackles the representations, ruptures, and developments in the field of CanLit from the roaring 1960s to the first decade of the unevenly globalized 21st century. Developed by an international team of specialists in Canadian Studies, this collection elegantly embroiders a tapestry of transdisciplinary methodological approaches - feminist theories of embodiment, queer studies, literary history, urban studies, environmental criticism, and cultural studies - from which to 
rethink Canadian Literature and criticism. From these myriad perspectives, readers are granted multiple points of entry into diverse traditions, topics, and themes within and beyond the (un)common denominator of CanLit.

Engaging with, while simultaneously contesting the nationalistic ghosts that continue to haunt the discipline of CanLit, the essays in this volume offer alternative conceptualizations of the common tropes of belonging, memory, border, and nation. A special emphasis is placed on canon formation (Howells) and the institutionalization of the discipline (Kamboureli), which are crucial elements in this discussion, particularly considering the unstable state of the humanities today. Howells's essay opens the collection with an examination of several literary histories that reflect the borderline position of Canadian literature and criticism between institutionalized frameworks and forces of resistance and subversion. As a result, paradox, tension, and unpredictability become crucial elements in understanding the functioning and circulation of CanLit as an assemblage of material and immaterial processes of institutionalization and creativity. Through an examination of Asian Canadian Studies' continuous state of becoming, Kamboureli explains how methodological exercises of disciplinary formation require the critic to pause or to "slow down" in an act of responsibility, and, I would add, potential pleasure.

Discussions of temporality, particularly processes of acceleration, occupy a central position in recent theorizations of the transnational and global frameworks; these are fields that have gained currency among scholars in Canadian Studies and have become crucial instruments to examine the literary and cultural processes within and beyond the nation-state (Diana Brydon and Marta Dvorák, eds. Crosstalk: Canadian and Global Imaginaries in Dialogue, Waterloo, ON: Wilfrid Laurier UP, 2012; Pilar Cuder-Domínguez, Belén Martín-Lucas, and Sonia Villegas-López, eds. Transnational Poetics: Asian Canadian Women's Fiction of the 1990s, Toronto: TSAR, 2011; Kit Dobson, Transnational Canadas: Anglo-Canadian Literature and Globalization, Waterloo, ON: Wilfrid Laurier UP, 2009). In her analysis of feminist and queer speculative fiction in this collection, Martín-Lucas repositions the concept of the transnational as an invaluable tool to examine the ways in which queer and racialized bodies are dehumanized, and rendered as monstrous, by received versions of multiculturalism. In contrast, the fictions of Hiromi Goto, Suzette Mayr, Larissa Lai, and Nalo Hopkinson, as Martín-Lucas contends, strategically assemble diverse posthuman bodies as sites of jouissance and resistance to neoliberal structures and other market-driven ideologies. With a focus on African Canadian writing by Lawrence Hill and Kim Barry Brunhuber, Fraile-Marco's essay further exposes the limitations of the colour-blind policies of the official multicultural predicament by examining the "transnational positionality of mixed race subjectivity" (77). Unveiling the problematic claims of post-racial discourses, the novels analyzed in this essay illustrate how race intersects with gender as socio-culturally constructed categories, largely exploited, while simultaneously capitalized, by neoliberal systems of power within and beyond the Canadian nation. Gender, sexuality, and the body also occupy a central position in Cavell's essay in the collection. Focusing on Jane Rule, who is deemed "queerly Canadian" (167), Cavell discusses how the notion of queer cultural memory can contribute to rethinking national tropes, often destabilizing heterosexist structures, monolithic conceptualizations of identity politics, and nationalistic ideologies. 
The affective assemblage of local, national, transnational, and global forces also shape current artistic representations of Canadian urban life, as Darias-Beautell's essay illustrates. In her analysis of contemporary depictions of Vancouver in several literary and artistic artifacts, Darias-Beautell discusses how the social construction of place is always already intertwined with material and affective structures, often contesting romanticized constructions of the city. With examples such as Lee Maracle's short story “Goodbye, Snauq" (2004) and Rebecca Belmore's performance piece "Vigil" (2002), Darias-Beautell further stresses the need to reinscribe global locales like Vancouver with the erased histories and presences of Aboriginal and First Nation populations. The centrality of affect, particularly trauma and guilt, in revisiting historical processes in the construction of the Canadian nation also occupies a crucial space in HernáezLerena's and Lacombe's essays in this collection. With a focus on the genre of confession narratives, Hernáez-Lerena analyzes Michael Crummey's River Thieves and its depiction of the demise of the Beothuk in the context of Newfoundland. Further seeking to destabilize canonical theorizations of CanLit, Lacombe strategically employs the concept of critical intimacy as a framework from which to examine the key role of indigenous writers and theorists in the 1990s in contesting and reimagining these historical, affective, and institutional processes. Returning to Puar's reference to the dissipation of time in her articulation of assemblage, it is relevant to note that Lacombe's interest in the recent present is ultimately both complemented and informed by the responsibility of the critic to position herself at the crossing between temporalities where the traces of the past and the pull of the future meet in productive ways. In different guises, the interest in transtemporality, translocationality, and transdisciplinarity certainly traverses all the essays in this collection. The result is a panoramic vision from where the readers can engage with the volume as an assemblage containing a multitude of unruly Penelopes, carefully mapping and tracing a crossborder archive that expands traditional conceptualizations of what is commonly understood as Canadian literature and its multiple ramifications. 